\title{
Reengineering of Manufacturing Business Process Utilising the Manufacturing Module of an ERP Application
}

\author{
I Putu Agastya Harta Pratama ${ }^{\mathrm{a} 1}$, I Made Sukarsa ${ }^{\mathrm{a} 2}$, Gusti Agung Ayu Putri ${ }^{\text {a3 }}$ \\ ${ }^{a}$ Department of Information Technology, Faculty of Engineering, Udayana University \\ Bukit Jimbaran, Bali, Indonesia 80361 \\ e-mail: ${ }^{1}$ agastya.harta@student.unud.ac.id, ${ }^{2}$ sukarsa@unud.ac.id, ${ }^{3}$ agung.ayuputri@unud.ac.id
}

\begin{abstract}
Abstrak
Perubahan signifikan terhadap pola konsumsi masyarakat modern Indonesia, yang semakin diperkuat dengan dukungan Pemerintah Republik Indonesia untuk memasuki era Revolusi Indonesia 4.0, telah mendorong perusahaan manufaktur untuk merancang prosesproses baru yang terotomatisasi dan melakukan transisi untuk menjadi sebuah satu kesatuan bisnis yang terdigitalisasi. Enterprise Resources Planning merupakan sebuah perangkat lunak yang memungkinkan terciptanya integrasi dan otomatisasi proses bisnis antara berbagai departemen dalam sebuah perusahaan, sehingga dapat menghasilkan strategi bisnis yang efektif. Data yang telah diperoleh dari penelitian pada perusahaan pemrosesan unggas kemudian dipetakan ke dalam perangkat lunak ERP Odoo V12.0, yang akan menciptakan beberapa hasil rekayasa bisnis proses. Terdapat beberapa hasil rekayasa bisnis proses- yang hanya terfokus pada departemen produksi perusahaan menggunakan modul manufacturing. Hasil rekayasa bisnis proses kemudian diujikan menggunakan teori Technology Acceptance Model untuk mengukur kegunaan dan kepraktisan daripada sistem, dengan nilai interpretasi skor likert di atas standar penerimaan, yakni sebesar 1340.
\end{abstract}

Kata kunci:, Enterprise Resources Planning, Odoo, Proses Manufaktur, Rekayasa Bisnis Proses, Technology Acceptance Model.

\begin{abstract}
The significant change in the consumption pattern of Indonesia's modernising societyfurther intensified by the Indonesian Government's plan to push towards the era of the Ind ustrial Revolution 4.0, has fostered the need for manufacturing companies to create newly automated processes and make the transition to become a digitalised business entity. Enterprise Resource Planning is a software that enables the creation of integration and automation of business processes between various departments within a company, thus creating an effective business strategy. The data that has been acquired from research at a poultry processing company are then being mapped into the ERP software of Odoo V12.0, therefore creating new sets of reengineered business processes. There are several newly proposed reengineering business processes - in which only concentrate on the production department within the particular company, by utilising the manufacturing module. The re-engineered business processes are assessed using the Technology Acceptance Model theory, to measure its usability and practicality, which generates the score of Likert's interpretation above the accepted standard of 1340, for the manufacturing module respectively.
\end{abstract}

Keywords: Business Process Reengineering, Enterprise Resource Planning, Manufacturing Process, Odoo, Technology Acceptance Model.

\section{Introduction}

According to a recent survey by Indonesia's National Development Planning Agency and the Food and Agriculture Organisation, has found that consumption of poultry-based meat will experience the highest projected increase of around $22.1 \%$ in 2025 or approximately 9.13 kilograms per capita each year [1]. Furthermore, the constant support and initiative by the Government of the Republic of Indonesia, to advance towards the era of Industrial Revolution 
4.0, has fostered the need for companies within the agribusiness sector-to take market share by creating new sets of automated processes and a digitalised business entity. In most cases, companies that are engaged in the manufacturing sector are quite familiar with the use of software in business activities. The usage of such software usually involves the calculation of production capacity-based on production factors, including the capabilities of production machines, raw material data, supply chain analysis, and available trained workforce.

This research was conducted at a poultry processing company located in Bali, Indonesia. With a maximum production capacity of up to 2000 units per hour (equivalent to 28.000 units per day), the company is categorised as a large-scale enterprise. Being one of the main distributors for well-known fast-food companies, this company is demanded to maintain its performance so that it can produce high-quality products and sustain customer satisfaction. This particular company itself is not using an integrated system throughout the departments, such as warehousing, purchasing, especially production, quality assurance, and technical departments-haven't yet to utilised any software to back its activities, thus most of the records are being done manually. The absence of an integrated and digitalised system within the company could increase the possibilities of mismanagement and miscommunication. This will lead to a decrease in one's business effectiveness.

Enterprise Resources Planning is a software that enables the creation of an integrated and automated process between various departments and entities within a company. Every single activity that has been made by any departments and entities, will be recorded digitally onto a single database. Subsequently, the other responding departments can access the records, and may cross-check if one encounters any mistakes. Having using such advantage, an ERP software is capable of establishing a seamless process throughout a company. With that being said, the use of the system tends to be costly and quite complicated to implement. Odoo is an Open-Source ERP software that has similar capabilities like other commercial ERP software, namely SAP and Microsoft Dynamics. ERP software that is open source are generally able to model existing business processes in the company [2]. The implementation of Odoo ERP Software is considered to be able to improve service quality through business process reengineering of the manufacturing process, specifically in the production and technical department.

The objectives of this research were established; aimed mainly for the production department of department of this company. First, is to achieve the integration of data flow from the manufacturing department with other departments in the company using the ERP Odoo V12.0 application by carrying out reengineering of business processes. Second, to further observe whether the ERP Odoo V12.0 application can produce best practice results to improve the quality and quantity of the company's production. Lastly, the research is conducted to analyse the impact on employee performance and the efficiency of the production process resulted from the implementation of the ERP Odoo V12.0 application, in the manufacturing and technical sections.

Several preceeding research samples are used as a reference towards writing this paper. One of which is from Winda et al. (2017), with the title of "Developing Manufacturing Application using Enterprise Resource Planning Concept" which emphasise the need for manufacturing company to have an integrated system for handling their problems, increasing the performance and efficiency-by implementing an ERP software, in which Odoo was used as a tool to costumise production schedule and other necessities [3]. Other research published by Gunjal et al. (2019), with the title of "A Study of ERP as A Change Management Tool in Manufacturing Companies," suggest that the implementation of ERP within a manufacturing company works as a great change management tool and beneficial in terms of tangible results at both in the macro and micro lebel. However, the call for adoption of certain factors that facilitate the change management process is necessary [4].

\section{Research Method}

The research was being conducted by following a certain methodology which includes, literature study, data collection, processing of acquired data, data analysis, and system implementation and testing. Odoo Community Edition Version 12.0 was chosen as a tool to assist the reengineering of the manufacturing business process. Figure below explains the flow of research methodology. 


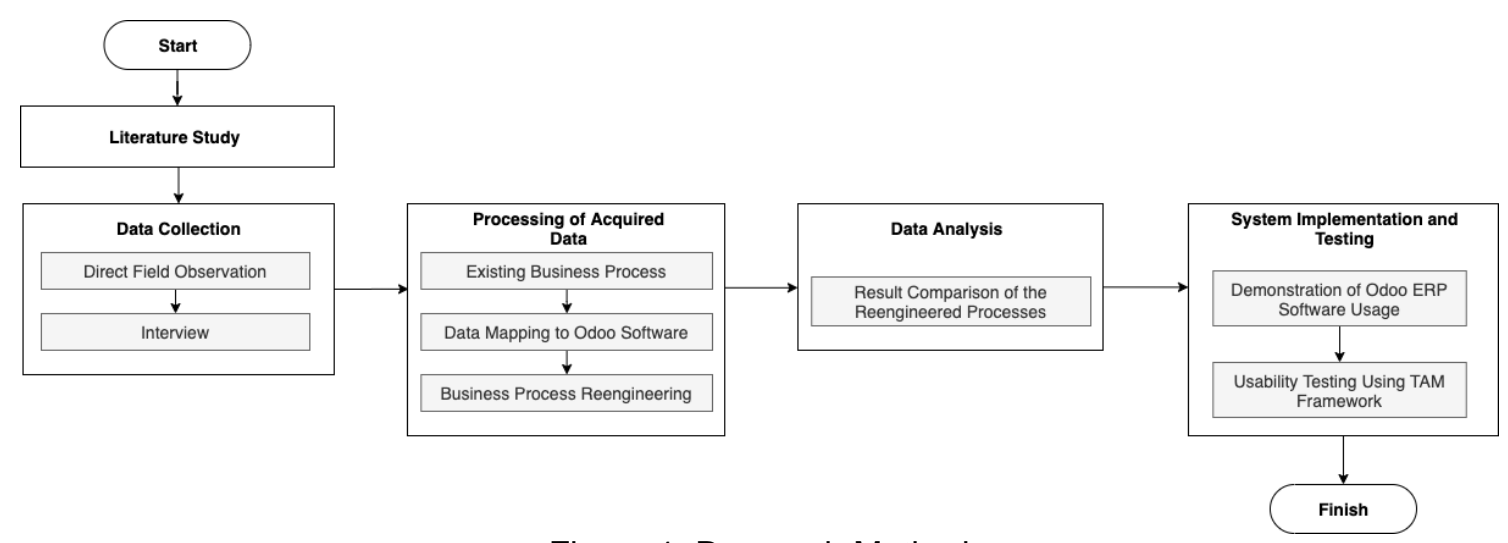

Figure 1. Research Method

\subsection{Literature Study}

Literature study is carried out by collecting information related to theoretical references based on the problems that have been identified [5]. This includes the theory of MRP, ERP, manufacturing process, production system, business process reengineering, and the Odoo software itself. Literature studies are obtained from several sources, including journals, books, articles, conference proceedings and scientific papers. This method is conducted to further strenghten the theoretical basis and objectives towards the research.

\subsection{Data Collection}

Data collection was carried out in two simultaneous ways, first one is by conducting a direct field observation to PT Ciomas Adisatwa and continued on by conducting interviews with personel related to the field of this research. Direct field observation is done by observing the existing company's business processes, emphasising on the manufacturing and the maintenance steps and processes [6]. This includes direct observation of the existing business processes in the manufacturing, quality assurance, technical, sales \& marketing, inventory, and purchasing department. The researcher then able to identify the flow of material and production factors. Interviews is another method of data collection, in which a continuation of the previous one. This is being done by conducting conversations with the operation managers of the responding departments, such as the head of production, head of quality assurance, head of warehouse, head of sales and marketing, and head of procurement.

\subsection{Processing of Acquired Data}

After data collection, the processing of acquired data will commence. The main step in data processing is mapping the data that has been obtained into the Odoo software. Furthermore, business process reengineering is carried out in accordance to the capabilities and mechanism of the Odoo ERP software.

\subsection{Data Analysis}

The reengineered business processes are later analysed, by creating a comparison to the existing business processes of the company. The comparison of both processes are illustrated using flowchart notations within a Standard Operating Procedure diagram, this will subsequently give out a deeper understanding of the reengineered results itself.

\subsection{System Implementation and Testing}

System implementation and testing are accomplished as a mean of measuring the system's feasibility based on previously analysed data. This is carried out by testing the newly implemented system and measure the user's perception and their acceptance. Sets of procedure are needed as an antecedent and carried out by performing various simulations of the software and its usage. The demonstration is performed live in front of several participants, including personnel within the department of production, quality assurance, technical, sales \& marketing, and warehousing. Also, several ERP system practitioners were included as supplementary. 
Following the procedures mentioned above, an instrument is needed to obtain the necessary data. A serie of questionnaire were designed as a tool to measure user's acceptance related to the scope of research, which is a 22 sets of questions of questionnaire for the manufacturing modules. The subject of those questionnaires are aimed for the department of manufacturing and quality assurance respectivelly. There are four constructs in each questionnaire, curated by following the four constructs of the TAM (Technology Acceptance Model) theory.

Technology Acceptance Model or TAM is a theory that measures user's acceptance towards the implementation and use of technology - a continuation from the Theory of Reasoned Action (TRA) which also model user's accepatance. TAM has the aim of explaining the determining factors in user acceptance of technology, as well as user behavior [7]. User acceptance is measured in two main constructs, namely perceived usefulness and perceived ease of use. In addition, TAM also measures the construct of subjective norms and user behavior control (behavorial control).

Perceived of usefulness (PU) is a construct which asses the use of technology can improve the performance and efficiency of the user's work, this construct is being used in both questionnaires - as a main instrument to validate the increase of effectiveness in employee's workloads [7]. Perceived ease of use (PEOU) is a construct that represents user characteristics based on the level of ease of technology operation. Perceived of attitude (PA) is a construct that measures and evaluates the user's attitude towards the use of a technology. Perceived of behavorial intention (PBI) is a construct that measures the user's further intention of using the system, this construct also measure the planned utilisation os such system in the forseeable future [8].

The questionnaires that have been mapped onto the TAM constructs, are then measured using 7-point likert scale instead of the conventional 5-points. A recent study from the Journal of Usability study, has found that using 7-point likert scale provides more accurate measure of participants' true evaluation, and are more sensitive to capture their assesment when a questionnaire is administered using an electronic non-moderated format. This is due to a higher frequency of respondent interpolations when 5-points likert are being used (11 interpolators), compared to a much less 0 interpolator of the 7-points likert scale. Interpolation is defined as a response outside the set bonds of the values such as, 3.5, $31 / 2,3$ and 4 [9]. The likert's scale is defined as 7 for "strongly agree," 6 for "agree," 5 for "somewhat agree," 4 for "neutral," 3 for "somewhat disagree," 2 for "disagree," and 1 for "strongly disagree."

\section{Literature Study}

References used in this study obtained from several sources, including journals, books, articles, conference proceedings and scientific papers. Data acquired from field observation, such as the current production and maintenance process, as well as company workflow, will also be written here.

\subsection{Business Process Reengineering}

According to Du Plessis, business process reengineering (BPR) is an analysis that is carried out fundamentally, as well as radical changes in every process and activity related to business - business practices, system management, organizational structure and business behavior of a company. The main goal that will be achieved is dramatically improved performance, to achieve contemporary requirements [10]. This research uses the six steps of Hammer and Chappy's BPR methodology, which are introduction into business reengineering (describes the existing business process), identification of business process (identifies all business processes related to the company - both internally and outside the company), selection of business process (choose the most suitable business process for the reengineering process), understanding of the selected process (measure the performance of the business process before the reengineering process is carried out, aims to provide comparisons of business process performance, before and after reeengineering), redesign the selected process (the process to be designed generally must focus on the point of view of customer satisfaction and the implementation of technology-based business processes), and the implementation of the redesigned processes [10]. 


\subsection{Manufacturing Process, Production System, and Quality Control}

The manufacturing process is one of the important stages of the production process of a product that will be produced in an industrial field. There are three basic types of a production process that are usually carried out in an industrial field, which are: job production (the production process is carried out only if the amount of production is small, but the goods to be produced sometimes have various models or variants), batch production (the production process is carried out repeatedly and the production flow framework has been predetermined or it can be concluded that the process of producing goods is carried out in batch units), and mass production (the production process carried out for products in large quantities and successively or continuous) [11].

The production system is a series of elements that are interconnected with the aim of processing-or processing input in the form of raw materials, intermediate products, components or assemblies, into end products with added value and its operation requires resources from technological and organizational elements [12]. Production system comprised of several activitiy, which are design, procure, produce, storing, deliver and service. There are four characteristics according to the purpose of its operation, which are assembly to order (manufacturers create standard designs, standard operational modules, later on the products are assembled according to modules and consumer demands), engineering to order (the customer asks the manufacturer to make a product starting from the design process), make to order (Work on a new product will be carried out after the product ordered has been decided by the consumer, in accordance with the specifications set by the consumer), make to stock (carry out production activities without waiting for the item order has been received, or production activities are completed before there is an order from the consumer) [12].

Quality control procedures are implemented to ensure that the products manufactured or the services performed adhere to a defined set of quality criteria or meet the requirements of the client or customer. The company has set a certain quality control points (QC points), using the conformity based on the HACCP (Hazard Analysis Critical Control Points), QMP (Quality Management Program), and ISO-9000. Data obtained from the reseach, also reveals that the company adopts several sampling methods in each QC points, namely the Military Standard 105E (MIL-STD-105E) and Continuous Sampling Plan (CMP). Military Standard 105E or commonly known as "MIL-STD-105E" is a reference for attribute sampling using the United States military standardization, is a reference for attribute sampling using United States military standards, aimed at ensuring that consumers get the highest quality product, and suppliers cannot imply that they can sell products with low quality or defects [13]. Meanwhile, Continuous Sampling Plan (CMP) is a sampling method in quality control procedures by inspecting each item while the production process is running [14]. Both of the sampling method uses the AQL or Acceptable Quality Level as a statistical measurement of the maximum acceptable number of defective goods. It should be noted, that the company uses MIL-STD-105E for most of the products that they're selling, unless a memorandum of understanding has been established with the costumer.

\subsection{Enterprise Resources Planning and Manufacturing Resources Planning (MRP II)}

Enterprise resource planning (ERP) is an integrated system of information able to accomodate the needs of information for specific departments within a company or enterprise. The use of ERP makes all systems in a company into one system that is integrated with one database, so that it becomes easier for several departments to share data, and make communication easier. Nowadays the ERP system is built using 3-tier achitecture, which are the presentation layer (accessing and using the system and/or gateway to the system), application layer (business rules, logical functions, and programs that receive / send from / to the database server), database layer (database management and its metadata).

MRP or Manufacturing Resource Planning is an explicit manufacturing information system that integrates major functions in the manufacturing industry, such as finance, marketing and production. The MRP II system covers and integrates all business aspects from industrial manufacturing companies, from business strategic planning at the top management level to detailed planning and control at the middle management and supervisor levels, then providing feedback to the managerial level above [11]. The MRP system requires three main inputs in the operation, which include: Master Production Schedule (planning activities in the production line), 
product structure and bill of material (components and structurisation of certain products), and inventory master file [15].

\subsection{Odoo Community Edition V12.0}

Odoo is an open-source ERP software based on python, which has lots of enterprise related applications to accomodate all business needs. This particular software has two versions, which are Odoo Enterprise Edition and Odoo Community Edition. The community version 12.0 of Odoo was chosen as a tool to establish business process reengineering, considering its flexibility and modularity as to the nature of open-sourceness from the software itself. Several modules are being used to establish the reengineered business process, and in this exact research the manufacturing and maintenance modules are being used as a mean to provide reengineering of business processes, specificaly within the departments of production and technical.

\section{Result and Discussion}

This particular section consists of the analysis of the reengineered business processes, obtained from the research, and the result of usability testing at the company-using TAM theory as an instrument of measure.

\section{1. $\quad$ Reengineering of Main Production Stages}

Reengineering of main production stages is a detailed reconstructed process of the production stages within the production department of this company. The production stages are then divided into two main intertwined processes using the routing and work centre in the manufacturing module of Odoo software. This reengineered process aimed to simplifies the system usage when it's being operated by the production operator. The simplification of the production process is divided into certain segments, following the two main sub-departments of the company's production department, namely the dirty area and the clean area. In addition, segmentation is carried out to categorise the production stages based on the final results to be achieved in each segment. The result of this particular reengineered process is ilustrated below.

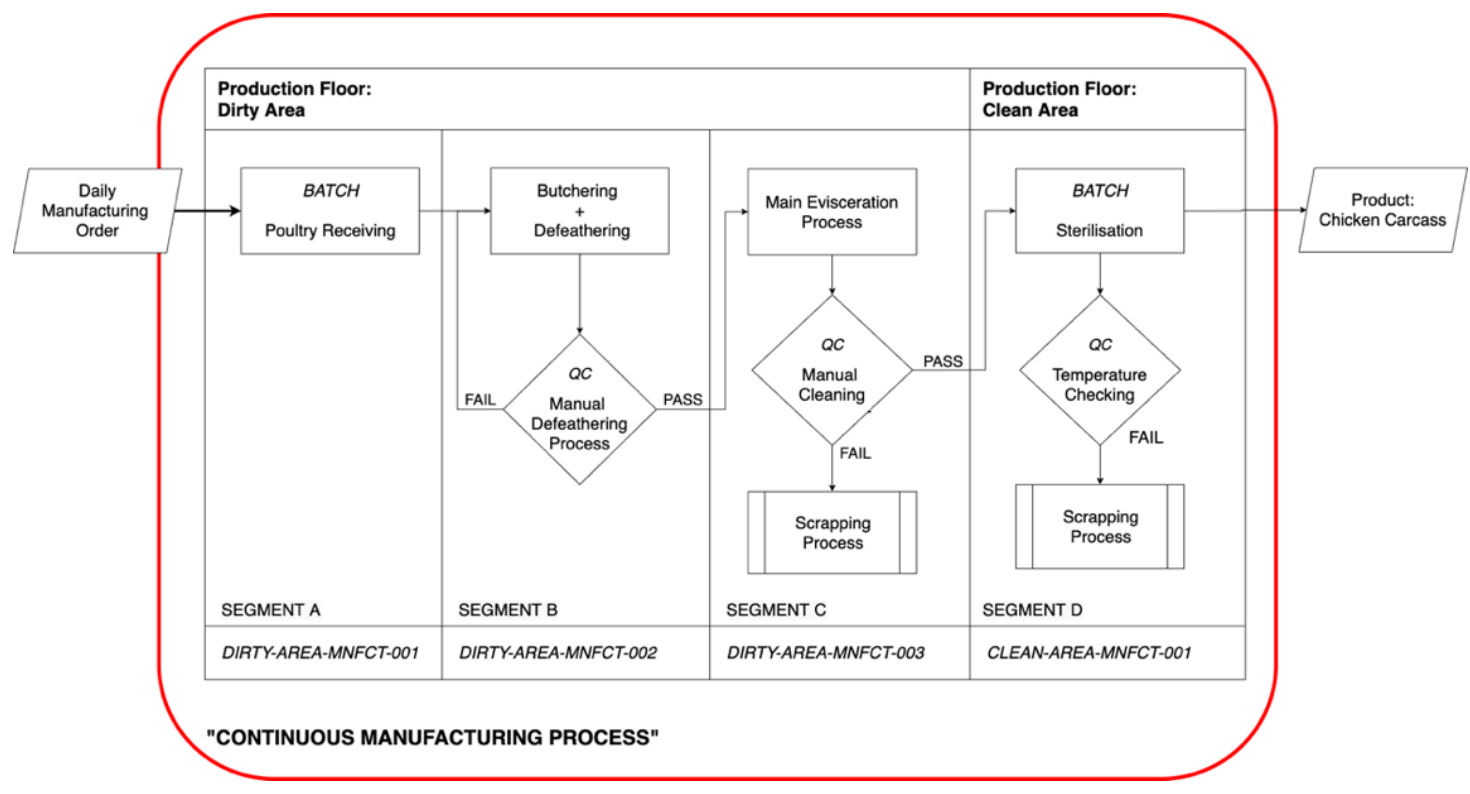




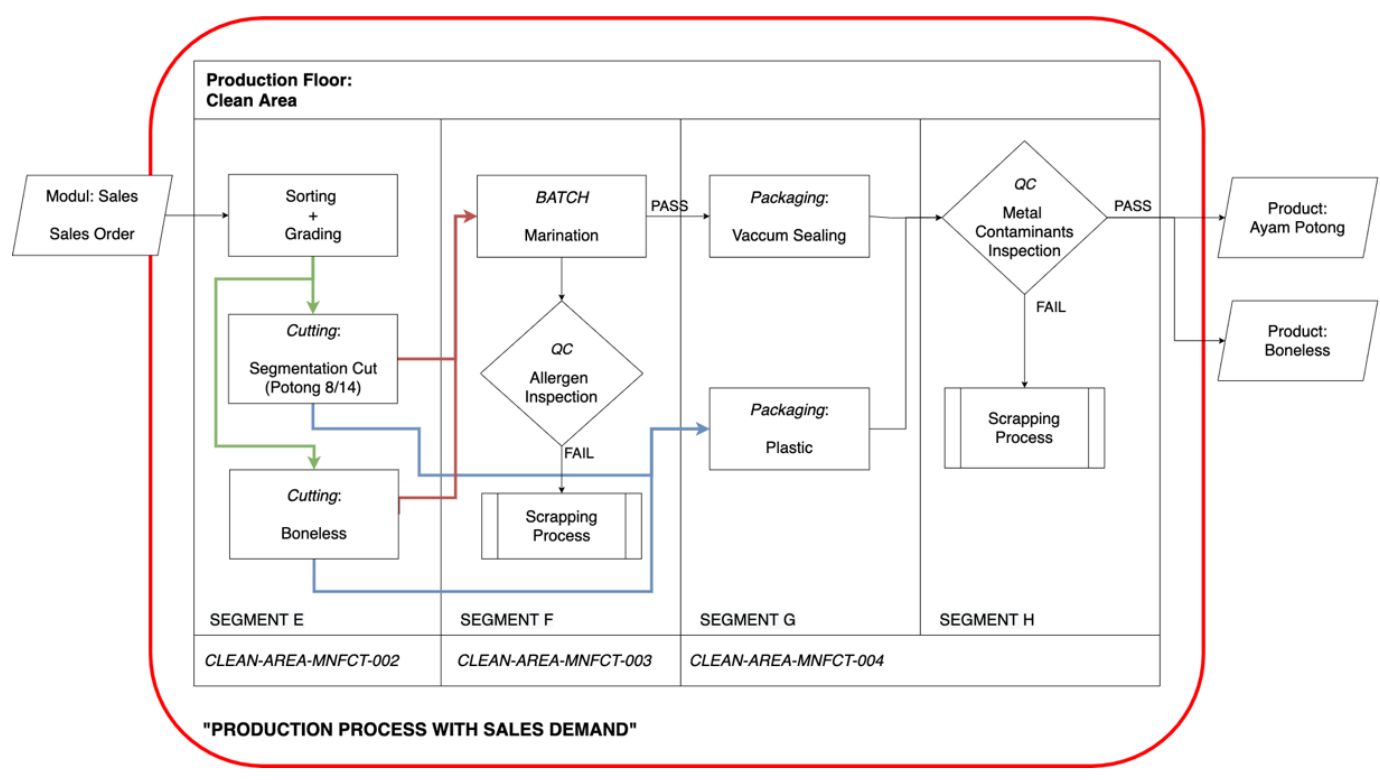

Figure 2. Reengineered Business Process of The Production Stages

The continuous production process is designed as a supplementary to the existing business process for some peculiar reasons, one of which is to avoid the stock-outs by creating an an additional quantity of an item held in the inventory, usually known as "safety stock." Third, this process aims for products with the aim of a "make to stock" production system, which do not have a specific specific process in their production activities (for example: the marination process), so that the production stages are always the same for each product. The utilisation of this process is by creating a set of daily manufacturing order (MO) within the Manufacturing module of Odoo, following the daily production quota set by the company's standard. The MO will be triggered automatically, thus giving the production operator an indication to start the production process. Figure below shows an example of the daily MO production quota using the Manufacturing module of Odoo, specified by the head department of production.

\begin{tabular}{|c|c|c|c|c|c|c|c|c|c|}
\hline Manufacturin & Overview & Operations Master Data Reporting Con & uration & & & & $C^{13} 2^{1}$ & 2 Agastya & \\
\hline Manufacturing Orde & ers / FP/MO/000: & 52 / Inventory Moves & & Search... & & & & & Q \\
\hline & & & & T Filters - $\equiv C$ & Group By - $\star$ Favorites - & & & $1-6 / 6$ & \langle\rangle \\
\hline$\square$ Date & Reference & Product & From - & & To & Quantity Done & Unit of $\mathrm{Me}$. & & Status \\
\hline 口 25/03/2021 21:11:19 & SP/00079 & [PRODUCT_FRESH_SEMI-001] Karkas Ayam & $\mathrm{CR} /$ stock & & Virtual Locations/Scrapped & & 0 Ekor NG (AY & m Karkas) & Done \\
\hline 25/03/2021 21:09:34 & SP/00078 & [MAIN_COMPONENT-001] Ayam Hidup & IP/Stock & & Virtual Locations/Scrapped & 2.00 & D Ekor NG (AY) & im Hidup) & Done \\
\hline 口 25/03/2021 21:10:27 & FP/MO/00052 & [MAIN_COMPONENT-001] Ayam Hidup & IP/Stock & & Virtual Locations/Production & 300.00 & $0 \mathrm{~kg}$ & & Done \\
\hline प 25/03/2021 21:10:27 & FP/MO/00052 & [PRODUCT_FRESH_SEMI-001] Karkas Ayam & Virtual Lo & cations/Production & CR/Stock & 200.00 & 0 Ekor NG (AY) & am Karkas) & Done \\
\hline प 25/03/2021 21:10:27 & PROD:FP/MO/00052 & [PRODUCT_FRESH_SELL-007] Usus Ayam & Virtual Lo & cations/Production & CR/Stock & $10,000.00$ & & & Done \\
\hline ㄴ 25/03/2021 21:10:27 & PROD:FP/MO/00052 & [PRODUCT_FRESH_SELL-006] Hati & Virtual Lo & cations/Production & $\mathrm{CR} /$ tock & $10,000.00$ & & & Done \\
\hline
\end{tabular}

Figure 3. Example of Daily Production Quota Using MO

Production process with sales demand is designed with the aim of carrying out production activities on products with certain criteria and specifications - those required by the customer, so that the production stages that are passed may vary for some products. This process is also being designed to avoid redudancy of the Production department by reducing the number of excessive production of products. This process is executed based on orders from the sales and marketing department, so this process can only be executed using the sales order in the sales module. Figure number 5 below shows an MO triggered from using the Sales module for the product of "Dada Paket Keluarga," this will automatically trigger the MO of FP/MP/00072 with the responding quantity of the product and the components of the products (shown on figure number 6) 


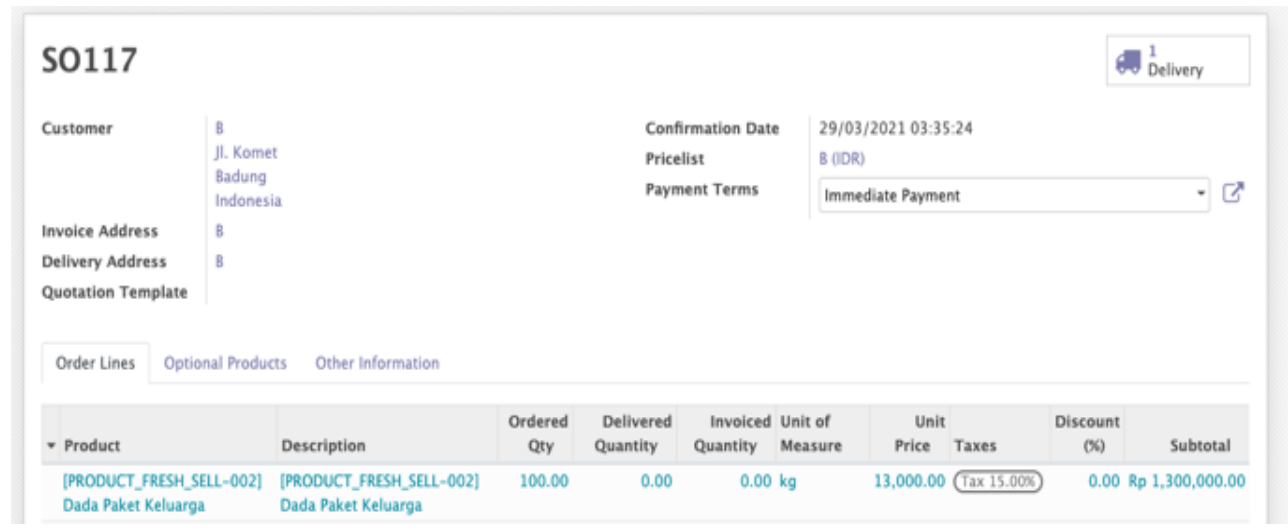

Figure 4. Creating Sales Order

\section{$\mathrm{FP} / \mathrm{MO} / 00072$}

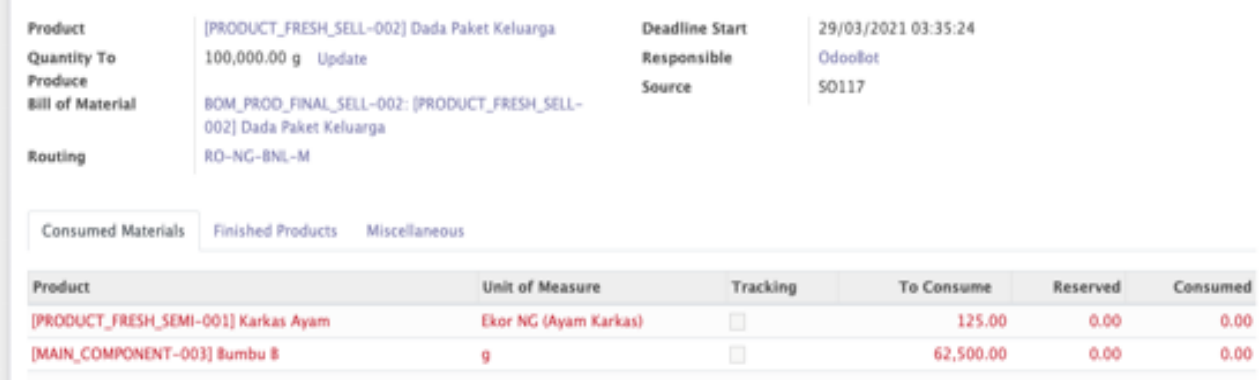

Figure 5. MO triggered by Sales Order

\subsection{Material Flow and Product Residual Management}

The material flow of these two given processes are managed accordingly using on the Bill of Material within the Manufacturing module of Odoo. Figure below explains the material flow from the responding reengineered main production stages, namely for the product of "Dada Paket Keluarga." The continuous production process will handle the raw materials (live chicken) -in an Incoming Product warehouse [inventory code: IP], and process it further to become a semi finished goods (chicken carcass) -in a Chill Room type warehouse [inventory code: CR]. This process will produce byproducts (residual products), namely chicken offals.

Furthermore, the production process with sales demand will handle semi finished goods-in a Chill Room type warehouse [inventory code: CR], and process it further to become designated chicken products, in accordance with the orders and demands received from the marketing department. This process will also produce byproducts such as wings and thighs. 


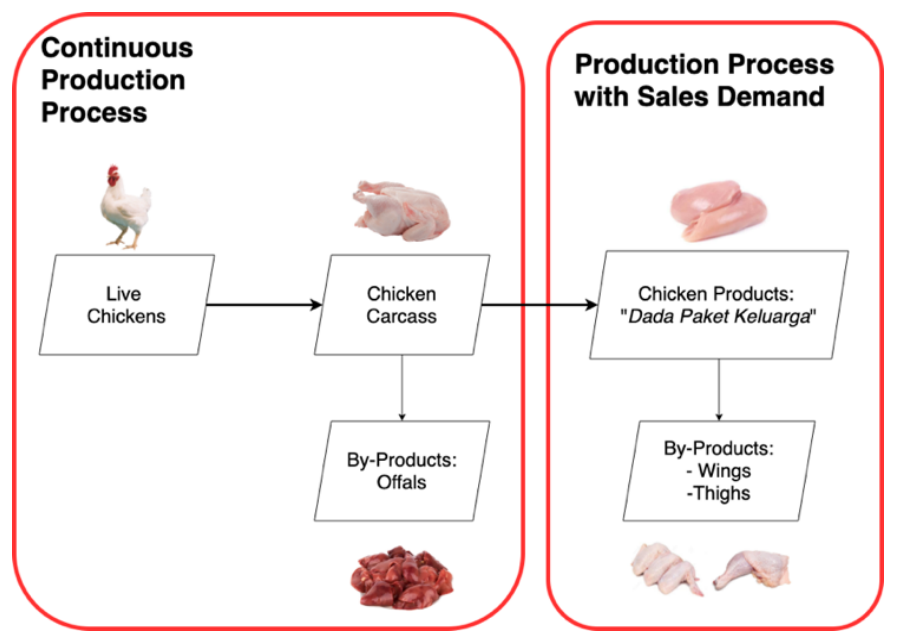

Figure 6. Detailed Material Flow

All of the byproducts that are being produced alongside the main products will also be recorded by the system automatically, based off of the information provided from the BOM. Figure below is an example to set product residual(s) using the Bill of Material and its outcome recorded on the system.

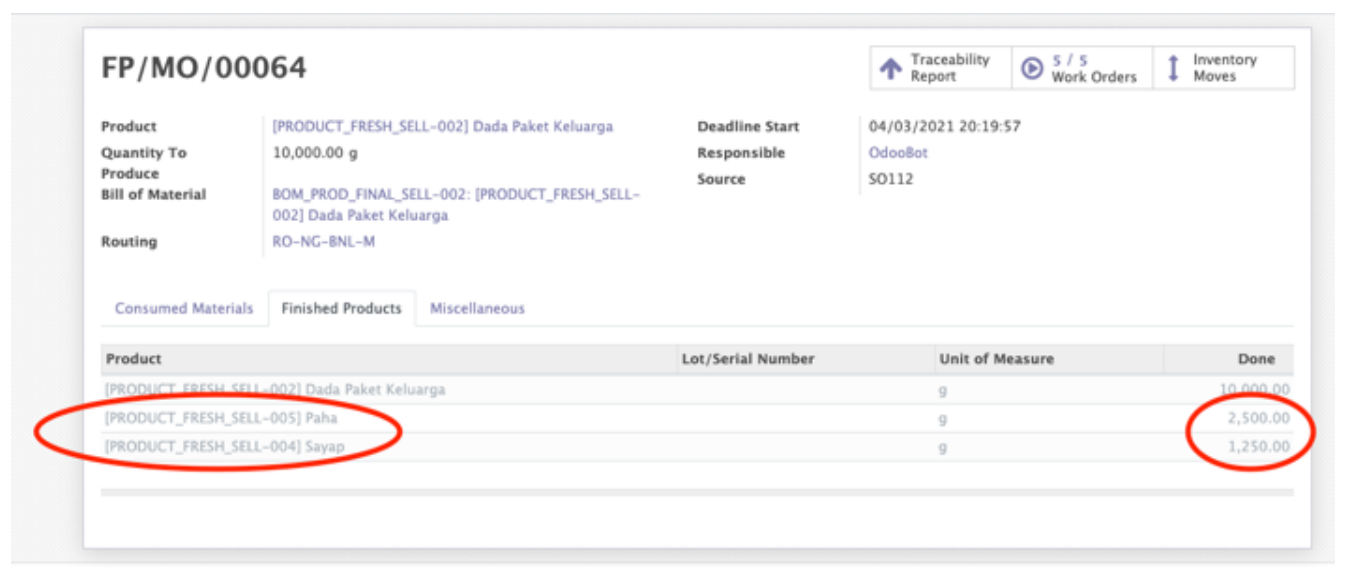

Figure 7. Management of Product Residual

\subsection{Quality Control with Scrapping Process}

Scrapping is an additional process of reprocessing manufactured goods due to loss of economic value, such as damage to goods during the production process, goods cannot be used due to expiration, and errors in the storage process. Scrapping is only done under certain conditions, that is, when a product fails to meet quality control standards and the product cannot be repaired, so the product is declared damaged. However, if the product can be repaired again, then the scrapping process does not need to be done.

This reengineering aims to provides detailed recording of which quality control points that have failed, and provides an acurate quantity value of the number of products that have failed and later to be reprocessed into saleable products by using a scrapping method. Figure below is a diagram of standard operating procedures comparison between the existing business process and the reengineered business process of the management of residual products. 


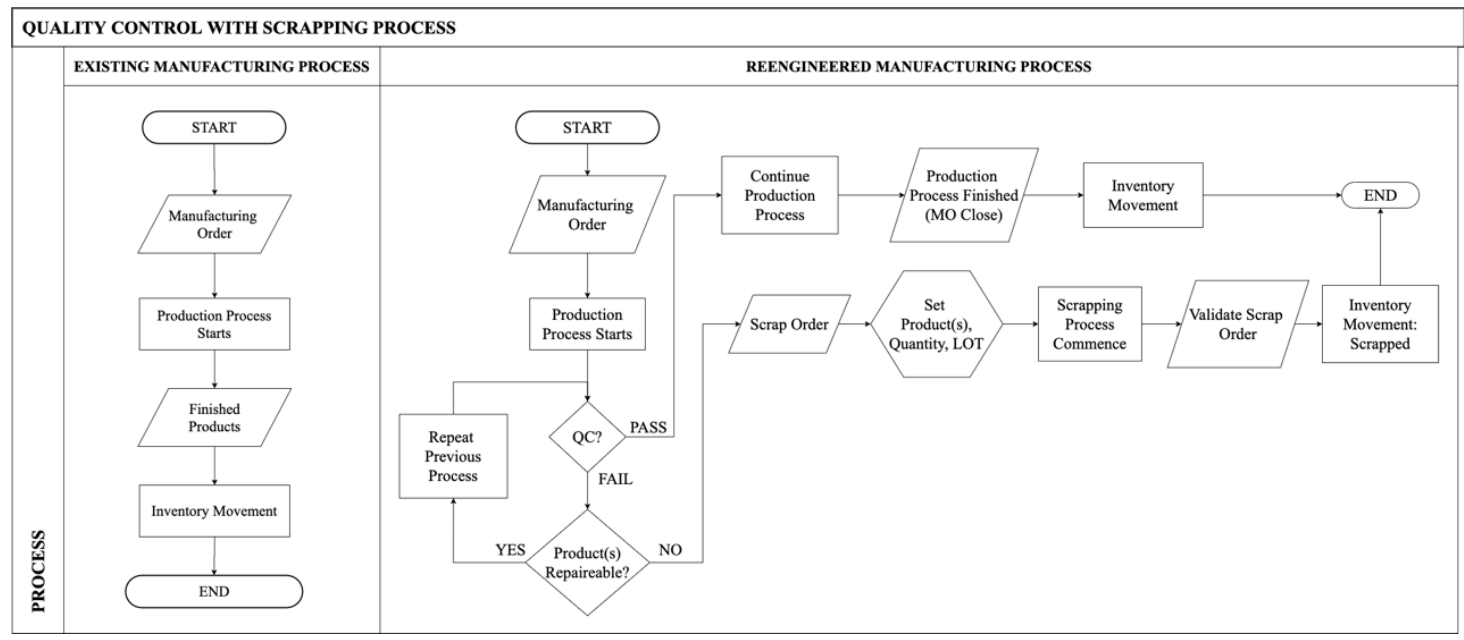

Figure 8. S.O.P of Quality Control with Scrapping Process

The Odoo software has the capability to carry out the scrapping process of a product, both during production activities and when the production process is complete. In order to assist the production personell in the course of using the system, specific codes has been assigned as a mean of guidance. Figure given below shows the series of codes used to indicate the QC method of each point and the scrapping procedure.

\begin{tabular}{|c|c|c|c|}
\hline RO/00028 & & (1) Time & Active \\
\hline Routing & Production Location & & \\
\hline Work Center Operations & & & \\
\hline - Operation & Work Center & & Duration \\
\hline BCH Poultry Receiving & DIRTY-AREA-MNFCT-001 & & $00: 00$ \\
\hline Butchering and Defeathering & DIRTY-AREA-MNFCT-002 & & 06:30 \\
\hline 1 QC NS-CONT Manual Defeathering Inspection & INSPECTION-DIRTY-AREA & & $00: 10$ \\
\hline Main Evisceration Process & DIRTY-AREA-MNFCT-003 & & 03:00 \\
\hline 2 QC S-CONT Manual Cleaning & INSPECTION-DIRTY-AREA & & $00: 20$ \\
\hline BCH Washing & CLEAN-AREA-MNFCT-001 & & 00:00 \\
\hline 3 QC S-RAND Temperature Check & INSPECTION-CLEAN-AREA & & $00: 20$ \\
\hline
\end{tabular}

Figure 9. Example of Designated Code Used in Routing

Number 1 and 2 show that the quality control process is carried out by carrying out the continuous sampling plan method (routing code: QC-CONT), where every product that has gone through the production stage is checked per-item (100\% conformity). Number 3 shows that the QC process is carried out by performing a random sampling method, where a quality control procedure is only carried out on a few randomized items (routing code: QC-RAND). The letter " $S$ " is given on some QC procedures (number 2 and 3 ), this is used to indicate that the scrapping process will be carried out - if the quality control procedure is declared to have failed. Meanwhile, the QC procedure with the letter code "NS" (number 1), states that if the quality control procedure fails, the scrapping process will not be carried out, and the previous production stage will be repeated.

\subsection{System Usability Testing}

Testing of the results of business reengineering of the manufacturing process is measured using the Technology Acceptance Model (TAM) theory with data collection techniques using a questionnaire. The data analysis from the questionnaire was carried out by measuring the Likert Summated Rating (LSR) for each construct from the questionnaire results. 
LSR is a measurement scale based on the attitude of the respondent. The data from the questionnaire were tabulated into Microsoft Excel software for calculations.

Table below shows the tabulated result from the questionnaire of the manufacturing module-using the TAM constructs. All of the constructs that were used within the questionnaire have received mostly positive response from the respondents-giving the overview the usage of such system has significant benefits towards the manufacturing department of the company and is easy to operate, hence the potential users have a high tendency to use the system in the near future.

Table 1. TAM Acceptance Percentage for Questionnaire of the Manufacturing Module

\begin{tabular}{l|l|c|c|c|c|c|c|c}
\hline No & \multicolumn{1}{|c|}{ Construct(s) } & \multicolumn{7}{c}{ Likert Point } \\
\cline { 3 - 8 } & & 1 & 2 & 3 & 4 & 5 & 6 & 7 \\
\hline 1 & $\begin{array}{l}\text { Perceived Usefulness } \\
(\mathrm{U})\end{array}$ & $0 \%$ & $0 \%$ & $0 \%$ & $1 \%$ & $13 \%$ & $\mathbf{4 8 \%}$ & $39 \%$ \\
\hline 2 & $\begin{array}{l}\text { Perceived Ease of Use } \\
(\text { EoU) }\end{array}$ & $0 \%$ & $0 \%$ & $0 \%$ & $6 \%$ & $20 \%$ & $\mathbf{5 6 \%}$ & $18 \%$ \\
\hline 3 & $\begin{array}{l}\text { Perceived Behavourial Intention } \\
(\mathrm{BI})\end{array}$ & $0 \%$ & $0 \%$ & $0 \%$ & $0 \%$ & $18 \%$ & $\mathbf{4 5 \%}$ & $38 \%$ \\
\hline 4 & $\begin{array}{l}\text { Perceived Attitude Toward Using } \\
(\mathrm{A})\end{array}$ & $0 \%$ & $0 \%$ & $0 \%$ & $2 \%$ & $22 \%$ & $\mathbf{5 0 \%}$ & $26 \%$ \\
\hline
\end{tabular}

Each of the questionnaires are then calculated and interpreted using the Likert Summated Rating method. First, the overall likert score rating will be masured multiplying each likert rating and the total responses to the questionnaire results for each construct. Table below shows the detailed interpretation of such calculation.

Table 2. Overall Likert Score Towards the Questionnare

\begin{tabular}{l|c|c|c|c|c|c|c}
\hline Likert Score & 1 & 2 & 3 & 4 & 5 & 6 & 7 \\
\hline $\begin{array}{l}\text { Total tallied } \\
\text { responses for each } \\
\begin{array}{l}\text { construct } \\
(\mathrm{EOU}+\mathrm{A}+\mathrm{U}+\mathrm{BI})\end{array}\end{array}$ & 0 & 0 & 0 & 5 & 38 & 109 & 68 \\
$\begin{array}{l}\text { Total likert scale to } \\
\text { the questionnaires }\end{array}$ & 0 & 0 & 0 & 20 & 190 & 654 & 476 \\
\hline Overall Likert Score & \multicolumn{1}{|l}{} & 1340 \\
\hline
\end{tabular}

Second, the yield of the ideal score are established by multiplying each likert rating with the ammount of questions of the questionnaire and the total respondents. In which the overall likert score will be categorised within the yield of this given score-shown on table 4 .

Table 3. Calculation of the Yield of Ideal Score

\begin{tabular}{l|c|c|c|c|c|c|c}
\hline Likert Score & 1 & 2 & 3 & 4 & 5 & 6 & 7 \\
\hline $\begin{array}{l}\text { Total Ammount of } \\
\text { Questions (22) }\end{array}$ & 22 & 44 & 66 & 88 & 110 & 132 & 154 \\
\hline Total respondents (10) & 220 & 440 & 660 & 880 & 1100 & 1320 & 1540 \\
\hline
\end{tabular}

Table 4. LSR Interpretation of the Manufacturing Module

\begin{tabular}{c|c|c|c|c|c|c|c|}
\hline LSR Interpretation of & \multicolumn{8}{|c|}{ Likert Score } \\
\cline { 2 - 9 } $\begin{array}{c}\text { the Manufacturing } \\
\text { Module }\end{array}$ & 220 & 440 & 660 & 880 & 1100 & 1320 & 1540 \\
\hline
\end{tabular}




\begin{tabular}{|c|c|c|c|c|c|c|c|}
\hline $\begin{array}{l}\text { "The system } \\
\text { implementation is } \\
\text { considered as very } \\
\text { unsuccessful (failed)" }\end{array}$ & \multicolumn{2}{|c|}{ Very Negative } & - & - & - & 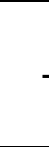 & - \\
\hline $\begin{array}{l}\text { "The system } \\
\text { implementation is } \\
\text { considered as } \\
\text { unsuccessful" }\end{array}$ & - & \multicolumn{2}{|c|}{ Negative } & - & 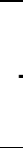 & - & - \\
\hline $\begin{array}{l}\text { "The system } \\
\text { implementation is } \\
\text { considered as quite } \\
\text { unsuccessful" }\end{array}$ & - & - & \multicolumn{2}{|c|}{$\begin{array}{l}\text { Somehow } \\
\text { Negative }\end{array}$} & 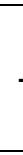 & - & - \\
\hline $\begin{array}{l}\text { "The system } \\
\text { implementation is } \\
\text { considered as quite } \\
\text { successful" }\end{array}$ & - & - & - & \multicolumn{2}{|c|}{$\begin{array}{c}\text { Somehow } \\
\text { Positive }\end{array}$} & - & - \\
\hline $\begin{array}{l}\text { "The system } \\
\text { implementation is } \\
\text { considered as } \\
\text { successful" }\end{array}$ & - & - & - & - & \multicolumn{2}{|c|}{ Positive } & - \\
\hline $\begin{array}{l}\text { "The system } \\
\text { implementation is } \\
\text { considered very } \\
\text { successful" }\end{array}$ & - & - & - & - & 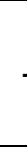 & \multicolumn{2}{|c|}{$\begin{array}{l}\text { Very Positive } \\
\text { (1340) }\end{array}$} \\
\hline
\end{tabular}

\section{Conclusion}

Several business processes that are currently running within the company are considered ineffective, due to the lack of integration of data flows between departments in the company and un-computerised recording. Therefore, it is necessary to carry out business process reengineering by mapping the ongoing business processes into the Odoo ERP system, where adjustments are made between the capabilities and functionality of the manufacturing and maintenance modules on the ongoing business processes on the Odoo ERP system. Business process reengineering is carried out to create a continuous flow of information between departments - especially in the production and technical sections of the company.

The system usability testing results using the TAM (Technology Acceptance Model) theory with Likert scale measurement, show that the Odoo V12.0 ERP system is successful to be accepted with an LSR (Likert Summated Rating) interpretation score of 1340 for the manufacturing module. The Usefulness construct in TAM, which measures the level of usability and performance and efficiency of users of a system, produces a positive response - with a total "agree" and "strongly agree" responses of $87 \%$ for the manufacturing module. The Ease of Use construct in TAM which measures the ease of users in using a system - also produces a positive response with a total response of "agree" and "strongly agree" of $74 \%$ for the manufacturing module.

\section{References}

[1] L. K. Sari, B. Arifin, N. A. Achsani, D. Martiano, and A. H. Firdaus, "Modeling the Future of Indonesian Food Consumption: Final Report," Jakarta, 2018. doi: 10.13140/RG.2.2.21079.32165.

[2] D. K. Mahardika, I. M. Sukarsa, and P. W. Buana, "Pemodelan ERP pada Perusahaan Manufaktur dengan Software OpenERP7.0," Merpati, vol. 2, no. 1, pp. 18-24, 2016, doi: $10.24843 / J I M$.

[3] I. Winda, I. Made, and I. Ketut, "Developing Manufacturing Application using Enterprise Resource Planning Concept," Int. J. Comput. Appl., vol. 164, no. 8, pp. 19-24, 2017, doi: 10.5120/ijca2017913709.

[4] S. GUNJAL and J. GOGTE, "a Study of Erp As a Change Management Tool in Manufacturing Companies," J. Manage., vol. 6, no. 2, pp. 105-110, 2019, doi: 10.34218/jom.6.2.2019.013.

[5] I. Afrianto and S. Atin, "The Journal Aggregator System Concept Using User Centered Design (UCD) Approach," Int. J. New Media Technol., vol. 5, no. 2, pp. 71-75, 2019, doi: 10.31937/ijnmt.v5i2.844. 
[6] C. R. Suwu, I. M. Sukarsa, and I. P. A. Bayupati, "Pengembangan Sistem HRM Terintegrasi Dengan Pendekatan ERP," Merpati, vol. 4, no. 3, pp. 259-270, 2016, doi: 10.24843/JIM.

[7] Jogiyanto, Sistem Informasi Keperilakukan. Yogyakarta: ANDI, 2007.

[8] K. Krismadinata, N. Jalinus, H. Pitra Rosmena, and Y. Yahfizham, "Understanding Behavioral Intention in Implementation of the ICTs Based on UTAUT Model," Lontar Komput. J. IIm. Teknol. Inf., vol. 10, no. 2, p. 96, 2019, doi: 10.24843/lkjiti.2019.v10.i02.p04.

[9] K. Finstad, "Response interpolation and scale sensitivity: Evidence against 5-point scales," J. Usability Stud., vol. 5, no. 3, pp. 104-110, 2010.

[10] S. Mohapatra, Business Process Reengineering: Automation Decision Points in Process Reengineering. London: Springer, 2013.

[11] C. Franjo, Manufacturing Information and Data Systems, no. 1. London, 2002.

[12] T. Baroto, Perencanaan dan Pengendalian Produksi. Yogyakarta: Graha IImu, 2002.

[13] NIST SEMATECH, "Choosing a Sampling Plan: MIL Standard 105D," Engineering Statistics Handbook, 2006. .

[14] K. K. Suresh and E. von Collani, "Continuous Sampling," Wiley StatsRef Stat. Ref. Online, pp. 1-5, 2014, doi: 10.1002/9781118445112.stat04209.

[15] S. Sinulingga, Perencaan dan Pengendalian Produksi. Yogyakarta: Graha IImu, 2009. 